\title{
KARAKTERISTIK HABITAT IKAN KERAPU DI KEPULAUAN KARIMUNJAWA, JAWA TENGAH
}

\section{THE CHARACTERISTIC HABITAT OF GROUPER FISH IN KARIMUNJAWA ISLANDS, CENTRAL JAVA}

\author{
Mujiyanto dan Amran Ronny Syam \\ Balai Penelitian Pemulihan dan Konservasi Sumberdaya Ikan \\ Teregistrasi I tanggal: 10 Oktober 2014; Diterima setelah perbaikan tanggal: 17 November 2015; \\ Disetujui terbit tanggal: 20 November 2015 \\ e-mail : antomj18@gmail.com
}

\begin{abstract}
ABSTRAK
Perairan Kepulauan Karimunjawa merupakan pemasok ikan kerapu bagi wilayah Pantai Utara Jawa. Permintaan dan harga pasar yang sangat tinggi mendorong nelayan lebih intensif dalam melakukan penangkapan ikan kerapu. Kegiatan penangkapan ikan kerapu selama ini dilakukan pada malam hari dengan alat bantu kompresor dan tembak. Kegiatan tersebut merupakan salah satu usaha untuk mendapatkan jumlah tangkapan yang tinggi tanpa memperhatikan kelestarian habitat dasar perairannya. Penelitian bertujuan untuk mengetahui keeratan hubungan ikan kerapu dengan karakteristik habitatnya. Metode yang digunakan adalah deskriptif eksploratif. Penelitian dilaksanakan selama 3 tahun (2011; 2012 dan 2013), waktu sampling masing-masing tahun penelitian berdasarkan musim. Pengamatan visual sensus sepanjang garis transek pada dua kedalaman 5$6 \mathrm{~m}$ dan 10-11 m. Hasil penelitian menunjukkan habitat ikan kerapu pada kedalaman $\pm 5-6$ meter adalah non karang serta substrat mati lainnya. Selain itu, ikan-ikan kerapu cenderung bergerak ke perairan yang lebih dalam. Karakteristik habitat pada kedalaman \pm 10 -11 meter menunjukkan ikan kerapu lebih menyukai dasar perairan dengan habitat karang keras yang didominasi oleh gundukan karang massive yang membentuk celah atau lubanglubang. Perilaku ikan kerapu bergerak dan berpasangan di tempat yang agak gelap (rendah visibilitas) dengan intensitas cahaya yang rendah. Perbedaan habitat kehidupan ikan kerapu pada kedalaman 5-6 dan 10-11 meter adalah dominasi karang jenis Pavona sp dengan tingkat visibilitas perairan yang rendah.
\end{abstract}

\section{KATA KUNCI: Habitat, ikan kerapu, kepulauan Karimunjawa}

\begin{abstract}
Karimunjawa Islands is a supplier of grouper fish for the north coast of Java. Grouper fishing activities have been carried out fishing done at night with a compressor and shooting aids. Fishing activity is an effort to get the number of catches were high regardless habitat resources of waters. The research aims to determine the correlation grouper fish with habitat characteristics. Method be used is descriptive exploratory method. The research was done in over three years (2011; 2012 and 2013), each sampling of research based on season time. The observations visual census along on line transect at two depths ( \pm 5-6 and $\pm 10-11$ meters). The results showed that habitat in depth \pm 5-6 meters, that grouper fish was found in non-reef habitats and other death substrates, as well as show grouper fish tend to move to deeper waters. Characteristics habitats in a depth of \pm 10-11 meters prefers bottom waters with hard coral habitats with dominated by massive coral mounds are a lot of gaps or holes. Behavior grouper fish move and paired witha low visibility (low intensity of light). Differences habitats of grouper fish life in depth $\pm 5-6$ and \pm 10 -11 meters is coral dominated by Pavona sp and low visibility of water level.
\end{abstract}

KEYWORDS: Habitat, grouper fish, Karimunjawa islands

\section{PENDAHULUAN}

Ikan kerapu tergolong dalam famili serranidae, memiliki kecenderungan hidup soliter dan merupakan jenis ikan bertipe hermaprodit protogini (Effendie, 2002). Ikan kerapu (grouper fish) merupakan kelompok yang paling intensif dieksploitasi dalam perdagangan ikan hidup karena memilki harga yang tinggi. Dorongan dari permintaan ekspor bagi konsumsi ikan masyarakat global saat ini semakin meningkat yang disebabkan oleh: a) meningkatnya jumlah penduduk disertai meningkatnya pendapatan masyarakat dunia, b) meningkatnya apresiasi terhadap makanan sehat sehingga mendorong konsumsi daging dari pola red meat ke white meat, c) adanya globalisasi menuntut adanya makanan yang bersifat universal, dan d) berjangkitnya penyakit hewan sumber protein hewani selain ikan sehingga produk perikanan menjadi pilihan alternatif terbaik (Kusumastanto, 2008; Adam, 2012). 
Permintaan sumber daya ikan terutama komoditas gouper fish dari pasar Hongkong sejak tahun 2000 hingga 2005, dengan terkirimnya komoditas tersebut sekitar 2.500 $\mathrm{kg}$ per tahun, sebagian besar dari alam (Campbell et al., 2013). Kebutuhan pasar ekspor tersebut memicu peningkatan eksploitasi ikan kerapu yang tidak ramah lingkungan yang mengakibatkan penurunan kualitas habitat dan sumberdaya ikan tersebut. Kondisi perairan itu dapat mengalami perubahan dan mempengaruhi kehidupan dan pertumbuhan ikan (Baskoro et al., 2010; Putri et al., 2013). Dengan demikian, habitat alami ikan kerapu menjadi kunci utama dari kelestarian sumberdaya ikan tersebut.

Tahap remaja dan dewasa dari beberapa jenis ikan kerapu, hidup di perairan pantai atau laguna dan muara, sedangkan tahap telur dan larva cenderung berada pada perairan lepas pantai yang jernih (Tupper \& Sheriff, 2008). Larva sebagian besar spesies kerapu bersifat planktonik selama 30-50 hari. Saat ikan kerapu menjadi remaja mereka menetap di perairan dangkal dan mencari perlindungan di padang lamun, akar bakau, pecahan karang, karang bercabang dan makroalga bercabang. Penyebaran vertikal tersebut sesuai dengan sifat ikan kerapu sebagai organisme yang pada siang hari lebih banyak bersembunyi pada habitat dasar yang celah-celah atau liang-liang karang, sedangkan pada malam hari aktif bergerak untuk mencari makan (Mariska \& Abdulgani, 2012).

Perairan Kepulauan Karimunjawa dikenal sebagai pemasok ikan kerapu di wilayah Pantai Utara Jawa, namun tidak diperhatikannya aspek masa pemijahan, siklus hidup dan kelestarian habitat ikan kerapu menyebabkan potensi tersebut menurun. Hal ini diduga karena ketidaktahuan atau kecenderungan nelayan berpatokan pada nilai jual ikan kerapu hidup yang sangat tinggi saja. Selain harga jual ikan kerapu hidup yang tinggi, ikan kerapu mati juga diperdagangkan di pasar lokal maupun di luar Kepulauan Karimunjawa dengan harga yang memadai. Pada musim pemijahan ikan kerapu, nelayan kompressor cenderung melakukan penangkapan karena dianggap sangat menguntungkan (hal ini dianggap sebagai panen raya). Penelitian ini bertujuan untuk mengetahui karakteristik habitat ikan kerapu, dengan penekanan pada upaya mempertahankan kelestarian sumberdaya ikan kerapu di alam.

\section{BAHANDANMETODE \\ Waktu dan Lokasi Penelitian}

Penelitian dilaksanakan di perairan Karimunjawa, Jawa Tengah selama tiga tahun penelitian, yaitu tahun 2011; 2012 dan 2013 (lokasi penelitian disajikan pada Gambar 1).

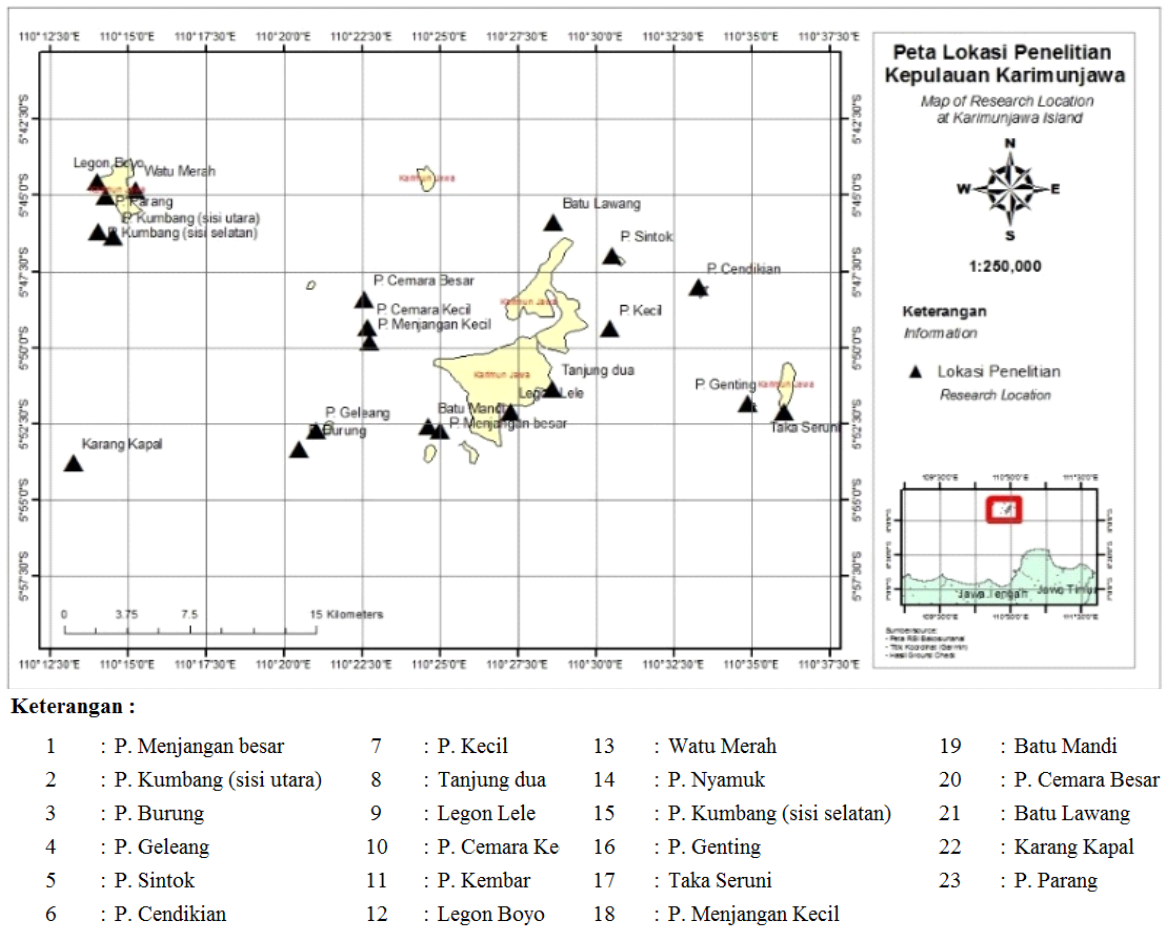

Gambar 1. Peta lokasi penelitian di Kepulauan Karimunjawa, Jawa Tengah.

Figure 1. Map of research location in Karimunjawa Islands, Central Java . 
Metode yang digunakan dalam penelitian ini adalah deskriptif eksploratif (Arikunto, 1993). Pengambilan data penutupan terumbu karang dilakukan dengan metode transek garis (Line Intercept Transect) yang dimodifikasi dari English et al., (1997) dengan peletakan garis transek pada kedalaman $\pm 5-6$ meter dan \pm 10 - 11 meter. Perbedaan kedalaman saat peletakan garis transek berhubungan erat terhadap pola hidup ikan pada masing-masing habitat dasar, kedalaman yang berbeda ( \pm 5-6 dan \pm 10 -11 meter) dapat memberikan perbedaan komunitas ikan secara stratifikasi (Mujiyanto \& Syam, 2014). Kedalaman penempatan transek mulai dari 0 meter sampai dengan 100 meter secara horizontal tidak memenuhi kedalaman tertentu, sehingga dibuat kisaran antar masing-masing kedalaman. Hal tersebut juga disebabkan adanya perbedaan kontur dasar perairan. Identifikasi jenis biota karang menggunakan panduan yang bersumber dari Veron (2000), identifikasi ikan karang menggunakan buku petunjuk bergambar yang bersumber dari Kuiter \& Tonozuka (2001); Allen et al., (2003) dan Tupper \& Sheriff, (2008).

\section{Analisis Data}

Persentase penutupan koloni karang dianalisis dengan rumus yang merujuk pada English et al., (1994) :

$\mathrm{L}=(\mathrm{Li} / \mathrm{N}) \times 100 \%$

\author{
Keterangan : \\ L : Persen penutupan karang \\ $\mathrm{Li}$ : Panjang koloni karang ke-i (cm) \\ $\mathrm{N}$ : Panjang transek $(75 \mathrm{~cm})$
}

Analisis untuk mendeterminasi sebaran karakteristik habitat antar stasiun pengamatan serta keeratan ikan kerapu dengan karakterisitik habitatnya digunakan analisis statistik multivariable yang didasarkan pada Analisis Komponen Utama Principal Componen Analysis (Legendre \& legendre, 1983; Bengen et al., 1992; Dodi et al., 2000). Analisis PCA menggunakan perangkat lunak program XLSTAT pada Microsoft excel 2010.

\section{HASIL DAN BAHASAN \\ Hasil}

\section{Persentase Tutupan Karang}

Hasil analisis tutupan karang pada kedalaman $\pm 5-6$ meter yaitu persentase karang keras (hard coral) berada pada kisaran 30,03-89,38 \% dengan persentase tutupan karang kategori sangat baik ditemukan pada stasiun Pulau Kecil (89,54\%), Pulau Kumbang-sisi selatan (81,17\%), Pulau Cemara Besar (80,38 \%) dan Pulau Menjangan Kecil sebesar 80,32 \%. Persentase tutupan karang lunak (soft coral) berada pada kisaran 0-5,75\% dimana prosentase karang lunakcukup tinggi ditemukan pada stasiun Pulau Burung, Karang Kapal, Legon Lele dan Pulau Geleang (Gambar 2, Lampiran 1 danLampiran 2).

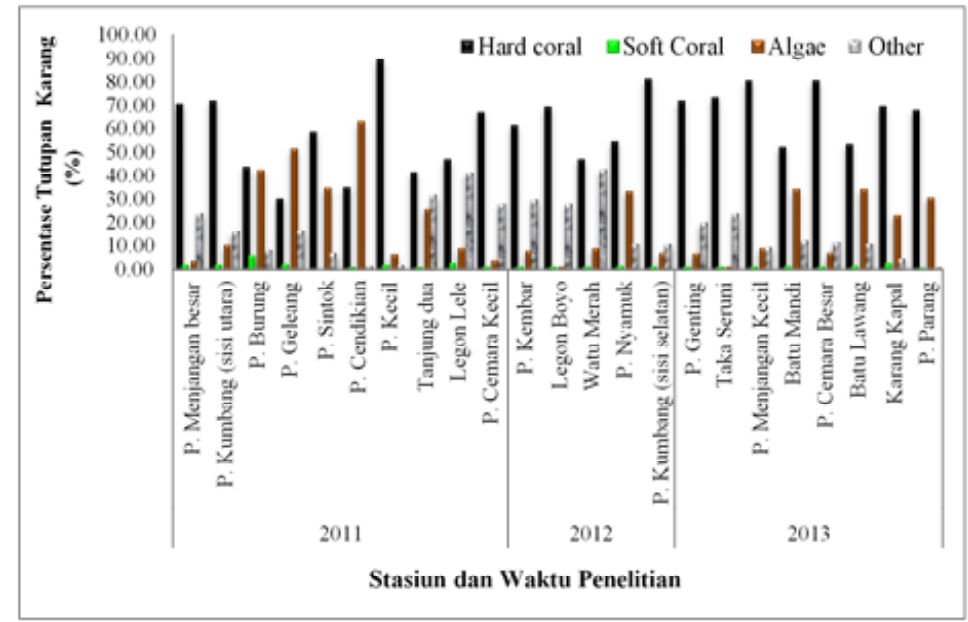

Gambar 2. Persentase tutupan karang di kedalaman +5-6 meter perairan Kepulauan Karimunjawa.

Figure 2. The percentage cover of coral at a depth of $\pm 5-6$ meters in Karimunjawa Islands waters.

Hasil sensus visual pada kedalaman $\pm 10-11$ meter persentase karang keras berkisar antara 30,54-89,55\% dengan persentase tutupan tertinggi pada stasiun Pulau Kecil (89,55 \%), Pulau Menjangan Kecil (86,22\%) dan stasiun Pulau Menjangan Besar sebesar 76,72 \% (Gambar 3). Persentase karang lunak berkisar 0-6,65 \% dengan tutupan cukup tinggi ditemukan di Pulau Parang, Pulau Kumbang, Pulau Burung, Pulau Cemara Besar, Tanjung Dua, Pulau Menjangan Besar dan Legon Lele.Tingginya persentase non karang (Alga) di stasiun Pulau Cendekian (58,53-62,70\%), Pulau Geleang (51,10-51,45\%), dan Pulau Burung (42,46-42,70 \%) dan persentase substrat mati di stasiun Taka Seruni (57,91 \%), Legon Boyo (54,45 \%), Legon Lele (41,33-53,12\%), WatuMerah(42,67\%)danPulau Kumbang $(40,89 \%)$ mengindikasikan bahwa pada beberapa stasiun yang merupakan bagian dari zona inti dan zona perlindungan Taman Nasional Karimunjawa telah terjadi kerusakan ekosistem terumbu karang (Gambar 3,Lampiran 1 danLampiran 2). 


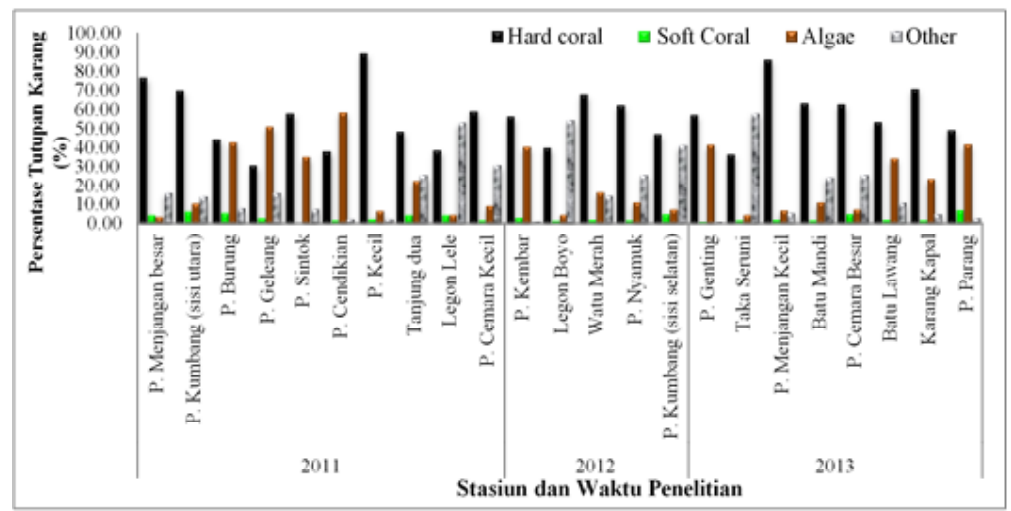

Gambar 3. Persentase tutupan karang di kedalaman $\pm 10-11$ meter perairan Kepulauan Karimunjawa.

Figure 3. The percentage cover of coral at a depth of \pm 10 -11meters in Karimunjawa Islands waters.

Hasil sensus visual terhadap tutupan karang pada kedalaman $\pm 5-6$ meter dan \pm 10 - 11 meter yang dibagi dalam 4 kelompok yaitu karang keras (hard coral), karang lunak (soft coral), golongan alga dan pasir, patahan-patahan karang, karang mati lainnya (other) disajikan pada pada Gambar 2 dan 3 (Lampiran 1).

\section{Keeratan habitat spawning aggregation ikan kerapu (grouper fish)}

Hasil analisis komponen utama (Gambar 4) keberadaan ikan kerapu dengan karakteristik habitatnya pada kedalaman $\pm 5-6$ meter menunjukkan adanya kecenderungan ikan kerapu lebih banyak dijumpai pada habitat patahan karang, karang mati, yang digolongkan pada kelompok habitat other, terutama pada lokasi pengamatan Tanjung Dua (St.8), Legon Lele (St.9), dan Watu Merah (St.13).

Hasil analisis yang tergambar pada Gambar 4 menunjukkan bahwa di daerah Tanjung Dua, Legon Lele dan Watu Merah lokasi didduga ketersediaan makanan lebih tinggi daripada daerah lainnya. Tingkah laku yang

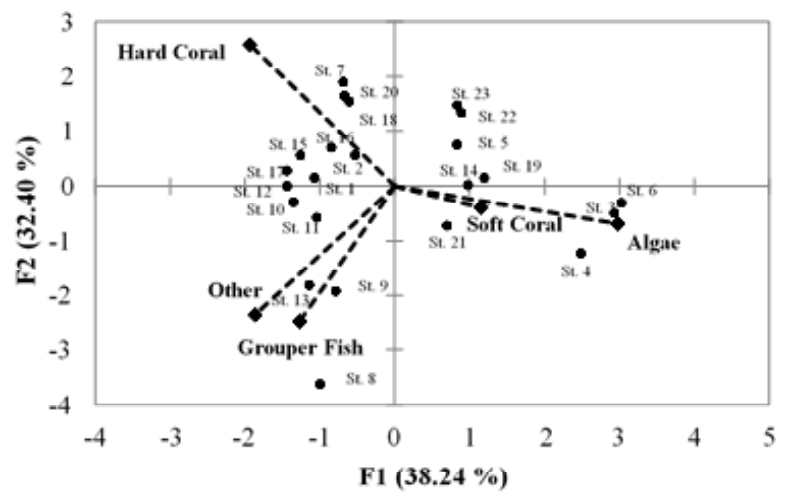

Gambar4. Sebaran keeratan ikan kerapu dengan karaketeristik habitat antar stasiun di kedalaman $\pm 5-6$ meter di perairan Kepulauan Karimunjawa.

Figure 4. Distribution of grouper closeness to habitat characteristics between stations at a depth of \pm 5 6 meters in Karimunjawa Islands waters. soliter memungkinkan ikan kerapu memangsa beberapa jenis ikan yang sedang mencari makan di patahan karang, daerah berpasir dan karang mati yang ditumbuhi alga. Kondisi habitat karang keras (hard coral) selama penelitian banyak ditemukan karang bercabang yang tidak mengindikasikan kehadiran jenis-jenis ikan kerapu.

Hasil analisis komponen utama (Gambar 5) menunjukkan keberadaan ikan kerapu cenderung pada habitat koloni karang keras (hard coral) pada kedalaman \pm 10 -11 meter, terutama pada lokasi P.Menjangan Besar (St.1), P.Kumbang (St.2), P.Kecil (St.7) dan P.Cemara Besar (St.20). Pada lokasi tersebut banyak ditemukan koloni karang keras dari genus Pavona sp. Beberapa karang keras pada kedalaman tersebut membentuk celah-celah atau lubang dengan dasar yang cukup dalam. Pola kesukaan terhadap habitat tersebut, diduga bahwa ikan-ikan kerapu memiliki kecenderungan menghindar dan mencari lubanglubang untuk persembunyian. Karakteristik tersebut memungkinkan ikan kerapu dewasa cenderungan bersembunyi pada karang-karang masive seperti halnya gundukan-gundukan karang dari genus pavona sp.

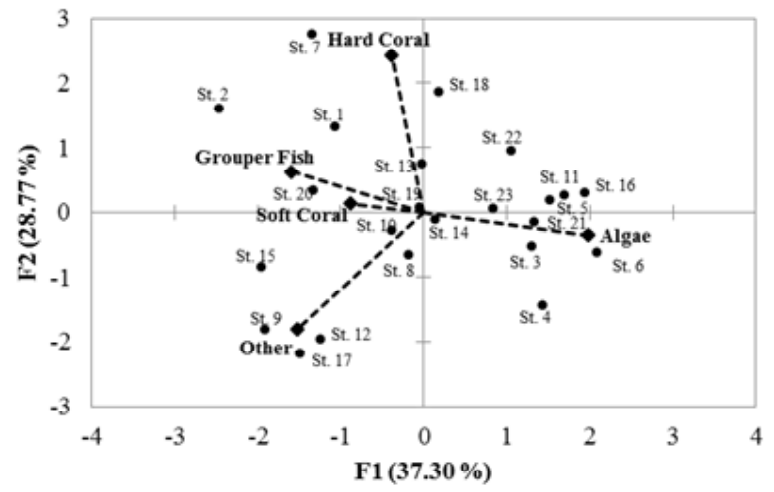

Gambar5. Sebaran keeratan ikan kerapu dengan karaketeristik habitat antar stasiun di kedalaman \pm 10 -11 meter di perairan Kepulauan Karimunjawa.

Figure 5. Distribution of grouper closeness to habitat characteristics between stations at a depth of \pm 10 IImeters in Karimunjawa Islands waters. 


\section{Bahasan}

\section{Persentase tutupan karang}

Penelitian untuk mengetahui karakteristik habitat ikan kerapu di perairan Kepulauan Karimunjawa dengan metode sensus visual tutupan karang pada kedalaman \pm 5 6 meter dan $\pm 10-11$ meter terbagi dalam 4 kelompok yaitu karang keras (hard coral), karang lunak (soft coral), golongan alga dan pasir, patahan-patahan karang, karang mati lainnya yang tidak teridentifikasi (other). Berdasarkan kategori persentase penutupan karang UNEP (1993). Kategori persentase tutupan karang diperairan Kepulauan Karimunjawa pada kedalaman $\pm 5-6$ meter berada pada kategori sedang hingga sangat baik dengan persentase 32,33-91,53\% dengan rata-rata persentase tutupan 63,27 $\%$, sedangkan pada kedalaman 10-11 meter, persentase tutupan karang juga berada pada kategori sedang hingga sangat baik dengan persentase 32,93-91,54\% dengan ratarata $59,40 \%$.

Hasil pengamatan WCS (2004) menunjukkan kondisi kesehatan terumbu karang di Kepulauan Karimunjawa secara umum dikategorikan baik, dengan nilai rata-rata persentase penutupan karang hidup sekitar $40 \%$ (Habibi et al., 2007). Hasil survey Reef Check Foundation tahun 1997-2000 menunjukkan persentase tutupan karang tertinggi tercatat pada tahun 2000 dan terendah pada tahun 1999, penutupan non-karang (abiotik) terendah pada tahun 2000 dan tertinggi pada tahun 1999. Hal ini diduga akibat meningkatnya intensitas penangkapan ikan dan biota laut lainnya dengan mengabaikan konsep kelestarian terumbu karang. Selain itu, semakin berkembangnya kegiatan wisata. Aktifitas penangkapan ikan dan biota pemakan algae menyebabkan konsentrasi algae di sekitar dan di permukaan karang menjadi tinggi sehingga mengganggu proses fotosintesa dari karang. Aktivitas wisata bahari seperti penyelaman juga memberikan kontribusi terhadap laju kerusakan akibat jangkar perahu atau terinjak penyelam pemula (Santoso \& Kardono, 2008).

Perubahan kondisi persentase tutupan karang disebabkan selain faktor tekanan aktifitas manusia, cukup tingginya persentase non karang juga diduga disebabkan oleh tekanan alam dimana beberapa stasiun berhadapan langsung dengan laut terbuka. Hasil penelitian tentang kondisi perairan karang di Kepulauan Seribu didapatkan pengaruh atau tekanan secara langsung terhadap faktor lingkungan perairan setiap waktu atau secara terusmenerus setiap musim. Hal tersebut merupakan lokasi perairan yang berada pada perairan terbuka (windward), sebaliknya apabila lokasi perairan tersebut berada pada daerah yang terlindung dari tekanan faktor lingkungan perairan atau adanya daerah daratan sebagai penghalang (barrier) terhadap pengaruh lingkungan disebut daerah perairan tertutup (leeward) (Sukarno et al., 1983 ; Panggabean \& Setiadji, 2011). Salah satu upaya pengurangan tekanan ekologis ekosistem karang dapat dilakukan melalui pembatasan aktifitas kegiatan perikanan, dan pariwisata serta kegiatan monitoring secara berkala pada beberapa lokasi di zona inti dan perlindungan.

\section{Keeratan habitat spawning aggregation ikan kerapu}

Beberapa jenis ikan kerapu pada waktu dewasa selama penelitian memiliki kecenderungan mencari celah-celah kecil dan cenderung bergerak ke perairan yang lebih dalam. Pergerakan kelompok ikan kerapu dewasa di perairan Caribbean dan Great Barrier Reef yang diungkapkan dalam penelitian Farmer et al. (2013) dan Rowell et al. (2015) menunjukkan pergerakan yang kompleks ke arah habitat pada kedalaman 15-20 meter. Hasil penelitiannya dengan menggunakan acoustic telemetry terhadap ikan kerapu ditemukan bahwa kelompok ikan kerapu yang siap memijah menunjukkan pergerakan (aggregation) pada kedalaman 30-50 meter. Pada kedalam tersebut komposisi jenis habitat dasar didominasi oleh alga dengan beberapa karang keras. Pada Gambar 4 menunjukkan ikan kerapu berada pada habitat kelompok biota lainnya (other). Hal ini diduga karena perlindungan diri sehingga mencari tempat persembunyian diantara karang-karang yang lebih aman baginya. Hasil penelitian Bulanin (2010) tentang keanekaragaman perbedaan jenis ikan kerapu yang ditemui pada terumbu karang disebabkan oleh perbedaan jenis karangnya. Ikan kerapu lebih banyak ditemukan pada karang batu yang memiliki celah tempat persembunyian sedangkan pada ikan hias lebih banyak sebagai penghuni pada karang bercabang. Tingginya kelimpahan ikan kerapu di Perairan Kota Padang pada stasiun penelitian terpilih, ditemukan bahwa kondisi tutupan karang hidup secara umum lebih menjukkan kelimpahan ikan kerapu dibandingkan dengan persentase tutupan karang yang rendah.

Perbedaan habitat terhadap kehadiran ikan kerapu pada kedalaman $\pm 5-6$ meter dan \pm 10 - 11 meter menunjukkan bahwa disamping habitat dasar sebagai tempat hidupnya, diduga terdapat beberapa faktor lain yang berpengaruh pada kehidupan ikan kerapu dewasa. Dominasi koloni karang keras pada kedalaman $\pm 10-11$ bukan didominasi oleh karang bercabang seperti kedalaman $\pm 5-6$ meter, tetapi didominasi oleh kumpulan karang massive yang membentuk formasi berupa celah-celah atau lubanglubang pada dasar. Hasil penelitian Heyman et al. (2004) menunjukkan beberapa ikan kerapu menjelang dewasa diduga memasuki tahap pemijahan biasanya berkumpul atau beragregasi pada kedalaman \pm 10 -15 meter atau berkumpul di tempat yang kecerahannya rendah (agak gelap) dan intensitas cahaya yang masuk ke dalam air sedikit. Giglio et al. (2014) dalam penelitianya tentang kelimpahan dan habitat ikan kerapu di Brazil ditemukan $63 \%$ (dari $\mathrm{n}=222)$ berada pada perairan dangkal $(0-14$ meter), hasil analisis terhadap ikan kerapu dewasa berada 
pada kedalaman rata-rata $22,3 \mathrm{~m}( \pm 6,7 \mathrm{sd})$, sedangkan remaja dan sub-adults yang diamati pada kedalaman ratarata $18 \mathrm{~m}( \pm 7.48 \mathrm{sd})$. Faktor lain yang dapat mempengaruhi pemijahan agregasi, yaitu parameter lingkungan perairan lainnya, karena hal ini diduga berpengaruh langsung pada penentuan penyebaran larva ikan.

\section{KESIMPULAN}

Karakteristik habitat ikan kerapu di perairan Kepulauan Karimunjawa pada kedalaman pengamatan yang berbeda ditemukan pada kedalaman \pm 5-6 meter habitat hidupnya berada pada terumbu karang dengan presentase karang keras antara 32,33-91,53\% atau rata-rata persentase tutupan $63,27 \%$. Sedangkan kedalaman $\pm 10-11$ meter habitatnya pada persentase terumbu karang antara 32,93$91,54 \%$ dengan rata-rata 59,40\%. Jenis-jenis habitat dasar pada kedalaman $\pm 5-6$ meter yaitu kelompok non acropora serta substrat mati lainnya. Habitat di kedalaman $\pm 10-11$ meter ikan kerapu lebih menyukai di dasar karang keras yang didominasi oleh karang massive yang membentuk celah atau lubang-lubang di dasar koloni karang. Perilaku ikan kerapu memilki kecenderungan kewilayah dengan kecerahan rendah (agak gelap) dengan pergerakannya cenderung bergerak ke perairan yang lebih dalam.

\section{PERSANTUNAN}

Karya Tulis Ilmiah ini merupakan kontribusi dari hasil kegiatan penelitian Kepulauan Karimunjawa, Jawa Tengah, Tahun Anggaran 2011; 2012 dan 2013, di Balai Penelitian Pemulihan dan Konservasi Sumberdaya Ikan, Jatiluhur. Penulis juga mengucapkan terima kasih kepada rekan-rekan FPIK UNDIP Semarang yang telah membantu pelaksanaan dan pengambilan data. Kegiatan ini merupakan bagian dari kerjasama FPIK-UNDIP dengan BP2KSI-BALITBANG KP-KKP.

\section{DAFTAR PUSTAKA}

Adam, L. 2012. Kebijakan pengembangan perikanan berkelanjutan (studi kasus: Kabupaten Wakatobi, Provinsi Sulawesi Tenggara dan Kabupaten Pulau Morotai, Provinsi Maluku Utara). Jurnal Perikanan dan Kelautan. Vol. II No. 2. Desember 2012: 115-126.

Allen, G.R, R. Steene, P. Human, N. Deloach, 2003. Fish Reef Identifiication : Tropical Pasific. Copyright, New Word Publications, Inc 2003. Printed By Standard Industries Pte Ltd. Singapore. 457 p.

Arikunto, 1993. Prosedur Penelitian, Suatu Pendekatan Praktek, Edisi Kesembi lan, Rineka Cipta, Jakarta. 56 pp.
Baskoro, Mulyono S., Taurusman, Am Azbas \& Sudirman. 2010. Tingkah Laku Ikan Hubungannya dengan Ilmu dan Teknologi Perikanan Tangkap. CV. Lubuk Agung. Bandung: 258 hal.

Bengen, D., Belaud, A. \& Lim, P. 1992. Structure et typologie ichtyenne de trois bras morts de la Garonne. Annales de Limnologie. 28: 35-56 p.

Bulanin, U. 2012. Potensi Dan Penyebaran Ikan Kerapu, Epinephelus miliaris, di Perairan Laut Kota Padang. Jurnal Mangrove dan Pesisir. X (1): 39-41.

Campbell, S.J, T. Kartawijaya, I. Yulianto, R. Prasetia \& J. Clifton, 2013. Co-management approaches and incentives improve management effectiveness in the Karimunjawa National Park, Indonesia. Journal Marine Policy: Elseivier. 41: 72-79.

Colin, P. L., Y. J. Sadovy, \& M. L. Domeier. 2003. Manual for the study and conservation of reef fish spawning aggregations. Special publication no. 1. Version 1.0. Society for the Conservation of Reef Fish Aggregations, San Diego, California. 70 p.

Darwisito, S., 2002. Makalah Pengantar Falsafah Sains (PPS702) Strategi Reproduksi Ikan Kerapu (Epinephelus sp.). Bogor:Program Pasca Sarjana/ S3 Institut Pertanian Bogor (2002). 15 p.

Dodi, S. M. Eidman, Dietriech G. Bengen \& S. Wouthuyzen, 2000. Distribusi spasial kerang darah (Anadara maculosa) dan iunteraksinya dengan karakteristik habitat di rataan terumbu Teluk Kotania, Seram Barat Maluku. Jurnal Ilmi-Ilmu Perairan dan Perikanan Indonesia. Vol. VII (2) MSP FPIK-IPB Bogor: 19-31.

Effendi, M.I. 2002. Biologi Perikanan. Yayasan Pustaka Nusatama. Yogyakarta. 92 p.

English S., C. Wilkinson, \& V. Baker, 1997. Survey Manual For Tropical Marine Resource (2 ${ }^{\text {nd }}$ Edition). Australian Institute of Marine Science. Australia. Hal. 41.

Farmer N.A., J.S. Ault, S.G. Smith \& E.C. Franklin. 2013. Methods for assessment of short-term coral reef fish movements within an acoustic array. Movement Ecology Journal. 1(2): 7 p.

Giglio, V.J, J. Adelir-Alves, L.C. Gerhardinger, F.C. Grecco, F.A. Daros \& Áthila A. Bertoncini. 2014. Habitat use and abundance of goliath grouper Epinephelus itajara in Brazil: a participative survey. Neotropical Ichthyology Journal. 12 (4): 803-810. 
Habibi, A. N. Setiasih dan J. Sartin. 2007. A Decade of Reef Check Monitoring: Indonesian Coral Reefs, Condition and Trends. The Indonesian Reef Check Network. 32 p.

Heyman, W., J. Azueta, O.F. Lara, I. Majil, D. Neal, B. Luckhur st, G. Paz, I. Morrison, K.L. Rhodes, B. Kjerfve, B. Wade \& N. Requena., 2004. Spawning Aggregation Monitoring Protocol for the Mesoamerican Reef and the Wider Caribbean. Version 2.0. Unpubl. M.S. Mesoamerican Barrier Reef Systems Project, Belize City, Belize. 55 pp.

Kuiter R.H \& T. Tonozuka. 2001.Indonesian reeffishes Part 1. Fisrt Published in 2001 by Zoonetic. Australia: 143.

Kusumastanto, T. 2008. Kebijakan dan Strategi Peningkatan Daya Saing Produk Perikanan Indonesia. Pusat Kajian Sumberdaya Pesisir dan Lautan. Tesis. Institut Pertanian Bogor. Bogor.

Legendre, L., \& P. Legendre. 1983. Numerical ecology. Develop. Environ. Model. V. 3. Elsevier: 510-512.

Mariskha P. R. \& N. Abdulgani, 2012. Aspek Reproduksi Ikan Kerapu Macan (Epinephelus sexfasciatus) di Perairan Kabupaten Pangkep, Sulawesi Selatan. Jurnal Sains dan Seni ITS Vol. 1 (1). E-27.

Muijyanto \& Amran. R. Syam, 2014. Distribusi Spasial Ikan Famili Chaetodontidae di Perairan Kepulauan Karimunjawa, Jawa Tengah. Jurnal Penelitian Perikanan Indonesia. Volume 20 Nomor 4. Desember 2014:225-234.

Panggabean, A. Sisco \& Setiadji, B. 2011. Bentuk Pertumbuhan Karang Daerah Tertutup dan Terbuka Di Perairan Sekitar Pulau Pamegaran, Teluk Jakarta. BAWAL: Widya Riset Perikanan Tangkap.Vol.3 No.4/ April 2011.7 p.

Putri, D.I. Lailatul, A. Tumulyadi \& Sukandar, 2013. Tingkah Laku Pemijahan, Pembenihan, Pembesaran
Ikan Kerapu Tikus (Cromileptes altivelis) Di Balai Budidaya Air Payau Situbondo. SPK Student JournalUniversitas Brawijaya. I(1): 11-15.

Rowell, T.J, Richard S. Nemeth, Michelle T. Schärer \& Richard S. Appeldoorn. 2015. Fish sound production and acoustic telemetry reveal behaviors and spatial patterns associated with spawning aggregations of two Caribbean groupers. Journal Marine Ecology Progress Series. Vol. 518./7 January: 239-254

Santoso, AD \& Kardono, 2008. Teknologi Konservasi dan Rehabilitasi Terumbu Karang. J.Tek.Lingkungan. 9 (3): 221-226.

Sukarno, M. Hutomo, M. K. Moosa, \& P. Prapto. 1983. Terumbu karang di Indonesia sumberdaya, permasalahan, dan pengelolaannya. Proyek Penelitian Potensi Sumber Alam Indonesia. Lembaga Oseanologi Nasional. Lembaga Ilmu Pengetahuan Indonesia. Jakarta.

Tupper, M. \& N. Sheriff. 2008. Capture-based aquaculture of groupers. In A. Lovatelli and P.F. Holthus (eds). Capture-based aquaculture. Global overview. FAO Fisheries Technical Paper. No. 508. Rome, FAO: 217253.

UNEP, 1993. Monitoring coral reefs for global change. Reference Methods for Marine Pollution Studies. (61): $72 \mathrm{pp}$.

Veron, J. E. N., 2000. Coral of Australia and Indo-Pasific. Angus \& Robertson Publisers. Australia: 463p.

WCS (Wildlife Conservation Society) Marine Program Indonesia. 2004. Laporan Teknis Wildlife Conservation Society Asia Pacific Coral Reef Program Indonesia Survei 2003-2004 di Kepulauan Karimunjawa, Jawa Tengah. Wildlife Conservation Society Asia Pacific Coral Reef Program Indonesia: Bogor: 66 hal. 
Lampiran 1. Data persentase tutupan karang dan kelimpahan ikan karang kedalaman pertama ( \pm 5-6 meter) di perairan Kepulauan Karimunjawa Jawa Tengah

Appendix 1. Data percentage cover coral and an abundance of reeffish in the first depth ( $\pm 5-6$ meters) Karimunjawa Islands, Central Java

\begin{tabular}{|c|c|c|c|c|c|c|c|}
\hline \multirow{2}{*}{$\begin{array}{c}\text { Tahun } \\
\text { Year }\end{array}$} & \multicolumn{2}{|r|}{ Stasiun Penelitian } & \multirow{2}{*}{$\begin{array}{c}\text { Karang } \\
\text { Keras } \\
(\%) \\
\text { Hard } \\
\text { Coral } \\
(\%)\end{array}$} & \multirow{2}{*}{$\begin{array}{c}\text { Karang } \\
\text { Lunak } \\
(\%) \\
\text { Soft } \\
\text { Coral } \\
(\%) \\
\end{array}$} & \multirow{2}{*}{$\begin{array}{c}\text { Alga } \\
(\%) \\
\begin{array}{c}\text { Algae } \\
(\%)\end{array}\end{array}$} & \multirow{2}{*}{$\begin{array}{c}\text { Substrat } \\
\text { Mati } \\
(\%) \\
\text { Other } \\
(\%)\end{array}$} & \multirow{2}{*}{$\begin{array}{l}\text { Kelimpahal } \\
\text { Ikan Kerap } \\
\text { (ind/ha) } \\
\text { Abundance } \\
\text { Grouper Fis } \\
\text { (ind/ha) }\end{array}$} \\
\hline & & Research Stations & & & & & \\
\hline \multirow[t]{10}{*}{2011} & 1. & P. Menjangan besar & 70.49 & 1.99 & 3.59 & 23.93 & 10.32 \\
\hline & 2. & P. Kumbang (sisi utara) & 71.78 & 1.99 & 10.27 & 15.95 & 6.95 \\
\hline & 3. & P. Burung & 43.65 & 5.75 & 42.46 & 8.13 & 1.26 \\
\hline & 4. & P. Geleang & 30.03 & 2.30 & 51.45 & 16.22 & 2.54 \\
\hline & 5. & P. Sintok & 58.35 & 0.00 & 34.81 & 6.84 & 1.14 \\
\hline & 6. & P. Cendikian & 34.88 & 1.01 & 62.70 & 1.41 & 0.46 \\
\hline & 7. & P. Kecil & 89.54 & 1.99 & 6.47 & 1.99 & 1.41 \\
\hline & 8. & Tanjung dua & 41.50 & 1.07 & 25.70 & 31.73 & 10.84 \\
\hline & 9. & Legon Lele & 47.07 & 2.67 & 8.93 & 41.33 & 11.76 \\
\hline & 10. & P. Cemara Kecil & 66.89 & 1.33 & 3.86 & 27.93 & 8.32 \\
\hline \multirow[t]{5}{*}{2012} & 11. & P. Kembar & 61.09 & 1.41 & 7.84 & 29.65 & 10.15 \\
\hline & 12. & Legon Boyo & 69.35 & 1.33 & 1.33 & 27.98 & 5.57 \\
\hline & 13. & Watu Merah & 47.07 & 1.33 & 8.93 & 42.67 & 25.61 \\
\hline & 14. & P. Nyamuk & 54.49 & 1.53 & 33.22 & 10.76 & 9.54 \\
\hline & 15 . & P. Kumbang ( sisi selatan) & 81.17 & 1.33 & 6.85 & 10.65 & 9.17 \\
\hline \multirow[t]{8}{*}{2013} & 16. & P. Genting & 71.94 & 1.41 & 6.66 & 19.98 & 6.09 \\
\hline & 17. & Taka Seruni & 73.33 & 1.33 & 1.33 & 24.00 & 21.33 \\
\hline & 18. & P. Menjangan Kecil & 80.32 & 1.34 & 8.97 & 9.37 & 18.37 \\
\hline & 19. & Batu Mandi & 52.10 & 1.54 & 34.34 & 12.02 & 5.32 \\
\hline & 20. & P. Cemara Besar & 80.38 & 1.34 & 6.90 & 11.39 & 1.18 \\
\hline & 21. & Batu Lawang & 53.37 & 1.53 & 34.29 & 10.81 & 19.09 \\
\hline & 22. & Karang Kapal & 69.61 & 2.68 & 23.16 & 4.55 & 16.92 \\
\hline & 23. & P. Parang & 67.82 & 0.66 & 30.59 & 0.93 & 3.70 \\
\hline
\end{tabular}

